\title{
Further Examination of the Market Valuation of Environmental Capital Expenditures by Pulp and Paper Companies
}

\author{
Perry W. Solheim \\ College of Business, Montana State University \\ PO Box 173040, Bozeman, MT 59717 USA
}

Tel: 1-406-600-1676E-mail: perry.solheim@ montana.edu

Received: February 09, 2012 Accepted: April 07, 2012 DOI: 10.5296/ijafr.v2i1.1544

\begin{abstract}
In this study I use the US pulp and paper industry to explore the equity market's valuation of environmental capital expenditures. I replicate and extend a study by Clarkson, Li, and Richardson that bifurcates the industry into high and low polluting groups. As with their study, I find evidence indicating that the market values environmental capital expenditures by over-compliant firms while attaching no such value to the same expenditures by minimally compliant firms. I do not find that the market assesses unrecorded liabilities to firms that are minimally compliant. My extension also seeks to address two possible specification issues in the Clarkson, et Al. approach. The first, levels model they used is unbiased but inefficient. Their model scaled by common shares outstanding attempts to rectify this inefficiency but may not be the optimal choice of scaling variable. My results suggest that a "Best Available Technology" approach to environmental regulation may carry additional incentives provided by the capital markets.
\end{abstract}

Keywords: Environmental capital expenditure, pulp and paper industry, regulatory incentives. 


\section{Introduction}

Do capital equity markets value environmental capital expenditures for companies in the U.S. pulp and paper industry? Traditional economic theory suggests that companies should expend only the minimum amount of resources necessary to meet environmental regulatory requirements. The emerging environmental economics literature offers several theories why companies might make the decision to devote excessive resources to environmental expenditures in order to over-comply with current regulatory requirements. An over-compliant firm's excessive environmental capital expenditures might lead to incremental benefits from the creation of "green goodwill", increased incentives to innovate, and/or the raising of costs for rival firms (resulting from a feature of U. S. environmental regulations that take a "Best Available Technology" approach to environmental control). Environmental capital expenditures by a minimally compliant firm only meet the costs of the environmental regulatory externality and provide the firm with no incremental economic benefit. This study seeks to test: 1) whether the market values any incremental benefits from environmental capital expenditures by over-compliant firms, 2) if the market assigns zero value to environmental capital expenditures by minimally compliant firms, and 3) whether the market anticipates unrecorded environmental liabilities for minimally compliant firms.

Current accounting standards require the capitalization of certain environmental expenditures due to the long-lived nature of the assets created. Critics of these standards argue that assets should only be capitalized if the asset provides some future incremental benefit. This study attempts to shed more light on the issue of future economic benefit of environmental expenditures. This study can also show the benefits to certain regulatory structures which utilize a "best in class" approach to standard setting.

My study is a replication an extension of a study by Clarkson, Li, and Richardson (2004), hereafter CLR, which examines the same research questions while examining firms in the pulp and paper industry during the period from 1989 to 2000. CLR use a pooled GLS regression technique to examine the levels of the relevant variables. Their study finds evidence indicating that the market values environmental capital expenditures by over-compliant firms while attaching no such value to the same expenditures by minimally compliant firms. Furthermore, they find that the market assesses unrecorded liabilities to firms that are minimally compliant. My study replicates their study for the period of 1993 to 2002 for the same industry, pulp and paper. I find similar evidence supporting their first two hypotheses regarding environmental capital expenditures by over and minimally compliant firms, but find no evidence of unrecorded liabilities for minimally compliant firms. These results provide evidence which is consistent with two of the three theoretical explanations of the cause of market valuation of environmental capital expenditure. I extend their study by examining the data using a returns specified model which examines changes in the relevant variables. Given the persistence that CLR find in firms maintaining a relatively constant level of environmental performance, I hypothesize that the market does not value increasing environmental capital expenditure by over-compliant firms because those firms have already achieved significant environmental performance. Furthermore, I 


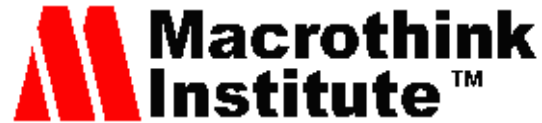

International Journal of Accounting and Financial Reporting ISSN 2162-3082 2012, Vol. 2, No. 1

anticipate that minimally compliant firms are punished by the market for increasing environmental capital expenditures in ineffective attempts to move to a best in class position. My extension also seeks to address two possible specification issues in the CLR approach. The first, unscaled, levels model used by CLR is unbiased but inefficient (Christie 1987). Their model scaled by common shares outstanding attempts to rectify this inefficiency but may not be the optimal choice of scaling variable (Christie 1987). My changes specification of the model attempts to circumvent these issues by examining changes in relevant variables thereby relieving the scaling issue. My results are consistent with my hypotheses.

The remainder of this paper is organized as follows: Section 2 reviews the relevant accounting and environmental economics literature, Section 3 explains the regulatory setting and develops the hypotheses to be tested, Section 4 presents the econometric models, Section 5 describes the sample selection, Section 6 contains the empirical results of the replication and new model specification and presents possible explanations for the inconsistencies, and Section 7 presents limitations, conclusions and suggestions for future examination.

\section{Accounting and Environmental Economics Background}

Copious accounting research has been concerned with how markets combine accounting information with non-accounting information to arrive at a firm's stock price. In the last decade, this type of research has begun to examine certain environmental measures as sources of "other" information. Campbell, Sefcik, and Soderstrom (1998) find that the number of Superfund sites of a firm in the chemical industry captures environmental risk. Barth and McNichols (1994) also look at Superfund sites to assess the likelihood of and levels of future environmental liabilities. Hughes (2000) employs the pollution measure of sulfur dioxide emissions to predict future environmental expenses. In all of these cases an environmental indicator serves as a proxy for some form of risk which represents information that can be used by the market in evaluating a firm's value. This study uses an environmental performance indicator (Toxic Release Inventory data from the EPA) to divide the industry of interest into two groups: high and low polluters. The market valuation of environmental capital expenditures is examined conditional upon this division. Feltham and Ohlson (1996) develop theoretical support for examining the valuation of current capital spending beyond current abnormal earnings. Their valuation model provides a framework for disaggregating current capital expenditures from book value for the purpose of examining market reaction to the isolated current capital spending.

The environmental economics literature provides three theories that explain why we might observe a valuation difference based upon the environmental performance of a firm: "green goodwill," incentives to innovate, and the raising of costs for rival firms.

The first explanation for a possible valuation difference arises from the concept of "green goodwill." The notion of "green goodwill" is that there are certain customers who will pay more for a product produced in an environmentally friendly manner. Arora and Gangopadhyay (1995) examine this possibility in the context of a duopoly game in which each of two firms chooses an emissions technology and a price for its product. Facing a 
segmented market, one firm may choose a more expensive emissions technology in order to become a low polluter and attract environmentally conscious customers. The pulp and paper industry produces a fairly homogenous product, but may enjoy "green goodwill" benefits from securing long-term contracts from the increasing number of companies practicing "green" supply-chain management (Walton et al. 1998).

Another explanation for a valuation difference comes from an increased incentive to innovate. In general, the nature of most pollution control strategies is tied to efficiency. Porter and van der Linde (1995) argue that low polluting firms improve operational efficiency by the employment of less costly materials, better utilization of materials in the production process and/or the conversion of former waste streams into inputs or new products. Low polluters thus have an increased incentive to innovate in their production processes. Empirical evidence consistent with this theory is presented by King and Lenox (2001) who find that low polluting firms have lower inventory levels compared to industry averages.

Finally, a valuation difference could result from differing environmental performance due to the ability of a firm to raise a rival firm's costs. Salop and Scheffman (1987) present a theoretical model in which a dominant firm can choose a cost-raising action that affects all the firms in an industry. Given certain regulatory settings, such as a "best available technology" approach, increasing environmental capital expenditures can cause competitor firms to have to play catch-up. Salop and Scheffman show that higher costs lead to an overall shift upward in the supply curve. If the price increase exceeds the average cost increase faced by the dominant firm, the dominant firm will employ the strategy because they will enjoy a higher profit margin.

\section{Regulatory Setting and Hypothesis Development}

The environmental regulatory setting in which the pulp and paper industry operates helps support two of the three theories mentioned above for a valuation difference between low and high polluting firms. Effluent guidelines for the industry are set by a regulatory framework of Best Available Technology (BAT) in which the average effluent quality is calculated over the top 50 percent of mills for a given time. This measure is then set as the acceptable level of effluent emissions (Clarkson et al. 2004). Thus the best environmental performers effectively set future environmental standards. The bifurcation of the industry into two groups, low polluters and high polluters, is supported by this regulatory approach. The present regulatory setting also supports the plausibility of valuation differentiation on the basis of increased incentives to innovate and raising the cost for rival firms.

Given the above environmental economic theories and the environmental regulatory setting faced by the pulp and paper industry, two hypotheses can be proposed:

H1: The market positively values environmental capital expenditures for low-polluting firms. 


\section{Mll Macrothink}

International Journal of Accounting and Financial Reporting

ISSN 2162-3082

2012, Vol. 2, No. 1

H2: The market assigns no value to the environmental capital expenditures of high-polluting firms.

The intuition behind the first hypothesis is that environmental capital expenditures represent some form of incremental economic benefit to the low-polluting firm through "green goodwill," increased incentives to innovate, and/or raising the costs for rival firms. The second hypothesis derives from theory that high-polluting firms do not enjoy these benefits.

The third hypothesis follows from the first two. Given that a high polluting firm will have to eventually meet the effluent standards of the low-polluting firms in the industry, the market has information that high-polluting firms face future environmental expenditures and thus face unrecorded liabilities. Therefore, the third hypothesis is proposed:

H3: The market assesses the existence of unbooked liabilities (future pollution abatement obligations) for high-polluting firms.

In extending the work done by CLR I rely on their conclusion about the consistent nature of environmental performance they find in their sample of pulp and paper companies. CLR conclude that it is difficult, expensive and time consuming for a high-polluting firm to become a low-polluting firm. Given this conclusion I would expect the market to not ascribe addition value to increases in environmental capital expenditures by firms who have already achieved low-polluting status. Furthermore, I would expect the market to realize the difficulty of a high-polluting firm's efforts to become a low-polluting firm and punish high-polluting firms for increasing environmental capital expenditure. Thus my two new hypotheses are as follows:

H4: The market does not value increases in environmental capital expenditures by firms established as low-polluters.

H5: The market will punish high-polluting firms that increase there environmental capital expenditures.

\section{Proxies and the Econometric Model}

The first step in testing the hypotheses presented above is constructing a measure for environmental performance. The measure of environmental performance used in this study is based on data acquired from the EPA's Toxic Release Inventory (TRI) database which collects and releases information about the release and transfer of toxic chemicals from manufacturing facilities. TRI data is publicly available through the EPA's website. Information is presented on a site by site basis and can be aggregated based upon parent company identification. TRI is the sum of all listed chemicals (in pounds) transferred or released to air, land or water in a particular year. Following Konar and Cohen (1997) I deflate TRI by cost of goods sold to arrive at a measure of pollution relative to productive output. This measure is then used to partition the sample into high and low-polluting firms based on scaled TRI relative to the median for the year. Environmental performance is 


\section{MIMacrothink}

International Journal of Accounting and Financial Reporting

ISSN 2162-3082

2012, Vol. 2, No. 1

relatively stable within my sample, with only four one year flip-flops of a firm changing from high-polluting to low-polluting or vice versa. These four single year anomalies give rise to some concern over the validity of the measure given that the entire industry is not represented in the sample. In order to address this issue analysis was run both including the flip-flops and also holding firms constant within environmental performance groups based on their median performance classification.

In order to examine whether the market impounds information related to environmental performance into valuation of environmental capital expenditures I first follow CLR and examine the hypotheses using a levels specification within the framework of a modified Ohlson (1995) valuation model. In this modified version of the Ohlson (1995) model, book value $(\mathrm{BV})$ is disaggregated into current capital expenditures (which is further disaggregated into environmental and non-environmental components) and an adjusted book value (ABV) consisting of the difference between total book value and current capital expenditures. The resulting empirical model is as follows:

$$
\begin{aligned}
& M V=\beta_{0}+\beta_{1} A B V+\beta_{2} E C E+\beta_{3} E C E^{*} P O L L U T E+\beta_{4} * N E C E \\
& +\beta_{5} N E C E^{*} P O L L U T E+\beta_{6} A E+\beta_{7} P O L L U T E+v
\end{aligned}
$$

MV = market value of common equity ( $\$ \mathrm{~mm})$, measured three months after the firm's fiscal year end;

$\mathrm{ABV}=$ adjusted book value of common equity equal to book value of common equity minus current period capital expenditure (ECE+NECE) $(\$ \mathrm{~mm})$;

$\mathrm{ECE}=$ current period environmental capital expenditure $(\$ \mathrm{~mm})$;

$\mathrm{NECE}=$ current period non-environmental capital expenditure $(\$ \mathrm{~mm})$;

$\mathrm{AE}=$ abnormal earnings to common defined as earnings to common equity less an assumed cost of capital based on the CAPM times beginning book value of common equity (\$mm);

POLLUTE $=$ indicator variable with value 1 for high-polluting firms, and 0 for low-polluting firms;

I calculate cost of equity based on the CAPM model $\left(\mathrm{COC}=\mathrm{R}_{\mathrm{f}}+\beta\left[\mathrm{E}\left(\mathrm{R}_{\mathrm{m}}\right)-\mathrm{R}_{\mathrm{f}}\right]\right.$ with $\beta$ calculated using 60 months of data updated annually. $R_{f}$ and $R_{m}$ are set to 4.5 and 6.5 percent respectively. Results were not affected when these estimates were varied between 3 to 5 and 6 to 8 . While this may not be the best empirical or theoretical measure of the cost of capital, it should be adequate for comparing the relative abnormal earnings between firms in this study. 


\section{Macrothink}

The coefficient tests are as follows:

$$
\begin{array}{ll}
\beta_{2}>0 & \text { (test of H1) } \\
\beta_{2}+\beta_{3}=0 & \text { (test of H2) } \\
\beta_{7}<0 & \text { (test of H3) }
\end{array}
$$

In extending the work by CLR I examine the relevant variables in the following specification:

$$
\begin{aligned}
& \triangle M V=\alpha_{0}+\alpha_{1} \triangle A B V+\alpha_{2} \Delta E C E+\alpha_{3} \Delta E C E * P O L L U T E+\alpha_{4} * \triangle N E C E \\
& +\alpha_{5} \Delta N E C E * P O L L U T E+\alpha_{6} \Delta A E+\alpha_{7} P O L L U T E+v
\end{aligned}
$$

$\Delta \mathrm{MV}=$ percent change in market value of common equity, measure three months after the firm's fiscal year end;

$\triangle \mathrm{ABV}=$ percent change in adjusted book value of common equity;

$\triangle \mathrm{ECE}=$ percent change in current period environmental capital expenditure;

$\triangle \mathrm{NECE}=$ percent change in current period non-environmental capital expenditure;

$\Delta \mathrm{AE}=$ percent change in abnormal earnings to common;

POLLUTE = indicator variable with value 1 for high-polluting firms, and 0 for low-polluting firms;

This model is estimated using an OLS specification. The OLS estimator is appropriate in this model because concerns over the serial correlation of errors are alleviated in a changes specification (Christie 1987). The tests of my hypotheses are as follows:

$\alpha_{2}=0$

(test of H4)

$$
\alpha_{2}+\alpha_{3}<0 \quad \text { (test of H5) }
$$

\section{Sample Selection}

My sample was drawn from companies on the Compustattapes which reported significant (>40\%) sales from pulp and paper operations during the years from 1993 to 2002. The sample was narrowed to companies with operations predominantly in the US to insure that operations where occurring in the regulatory environment of interest. This resulted in a sample of approximately 30 pulp and paper companies. Data was then hand collected from 


\section{Macrothink}

International Journal of Accounting and Financial Reporting

ISSN 2162-3082

10-K's and annual reports on environmental and total capital expenditures. Despite SEC MD\&A requirements for reporting the estimated capital cost of future environmental compliance, 8 of the companies never reported any historical environmental capital expenditures. Missing ECE data, pricing information and years when companies did not exist during the sample period resulted in a final sample of 149 firm years from 23 companies. By contrast, the sample in CLR's study consisted of 256 firm-years. Total environmental capital expenditure by the 23 sample companies for the 10 year period amounted to $\$ 6.13$ billion or $88 \%$ of the industry's total $\$ 7.04$ billion expended for pollution abatement during that period (NCASI 2002).

Panel A of Table 1 includes descriptive statistics for regression variables. Panel B of Table 1 includes distribution statistics for the regression variables as well as other variables of possible interested disaggregated by the POLLUTE indicator. Finally, Panel C of Table 1 presents a Pearson correlation matrix after scaling all variables other than TRI by common shares outstanding. A number of correlations are greater than .7 with significance. This may make the significance of the coefficients more difficult to show.

Table 1: Descriptive Statistics for a Sample of Pulp and Paper Companies during the Period 1993-2002

Panel A: Distribution Statistics, n=149 firm-years

\begin{tabular}{llllll} 
Measure & Mean & Std. Dev. & Median & Minimum & Maximum \\
\hline MV & 5,185 & 6,912 & 2,609 & 25 & 36,178 \\
BV & 2,378 & 2,484 & 1,663 & 0 & 12,354 \\
ABV & 1,955 & 2,098 & 1,347 & 0 & 10,682 \\
ECE & 41 & 46 & 24 & 0 & 262 \\
NECE & 382 & 340 & 292 & 0 & 1,410 \\
AE & 39 & 378 & 5 & $-1,894$ & 1,486 \\
TRI/COGS & 2,078 & 2,530 & 1,721 & 0 & 17,478
\end{tabular}


Panel B: Bifurcated Distributional Statistics, 12 Low-Polluters, 11 High-Polluters, n=149 firm-years

HIGH POLLUTERS

MEAN

$4,601.24$

$2,768.17$

$2,288.74$

50.28

$2,265.38$

$1,606.00$

$1,247.56$

23.80

429.15

280.65

3.10

0.97

0.60

0.09

$2,744.50$

0.01

0.62

0.10

$3,519.17$

0.01
MEDIAN

LOW POLLUTERS

MEAN MEDIAN

$5,939.06$

$2,700.44$

$1,873.54$

$1,815.85$

$1,523.56$

$1,505.74$

29.40

24.00

320.58

299.94

128.51

11.02

LEVERAGE

ASSET AGE

0.01 
Panel C: Pearson Correlation Matrix of Variables

MV

ABV

ECE

NECE

$\mathrm{AE}$

TRI/COGS

MV

1.000

ABV

$0.701 * * \quad 1.000$

ECE

0.528

$* 0.730$

1.000

NECE

0.712

* 0.804

** 0.725

1.000

$\mathrm{AE}$

$0.435 \quad * * \quad-0.041$

0.088

0.173

1.000

TRI/COGS

$-0.121$

0.007

0.008

$-0.006$

0.283

1.000

*and ** denotes significance at the 5 and 1 percent levels, respectively.

MV

market value of common equity $(\$ \mathrm{~mm})$, measured three months after the firm's fiscal year end;

$\mathrm{ABV}=$ adjusted book value of common equity equal to book value of common equity minus current period capital expenditure

$(\mathrm{ECE}+\mathrm{NECE})(\$ \mathrm{~mm})$;

ECE $=$ current period environmental capital expenditure $(\$ \mathrm{~mm})$;

NECE $\quad=$ current period non-environmental capital expenditure $(\$ \mathrm{~mm})$; 


\section{Macrothink}

International Journal of Accounting and Financial Reporting

$\mathrm{AE}=$ abnormal earnings to common defined as earnings to common equity less an assumed cost of capital based on the CAPM times

beginning book value of common equity $(\$ \mathrm{~mm})$;

POLLUT = indicator variable with value 1 for high-polluting firms, and 0 for low-polluting firms;

LEVERAGE = the ratio of long-term debt to equity;

ASSET AGE = age of capital equipment calculated as the ratio of net capital equipment to gross capital equipment;

LIQUIDITY $=$ the ratio of cash flow from operations to sales;

\section{Empirical Analysis}

Following CLR, I conduct my initial analysis on the pooled sample of firm-year observations using a pooled GLS technique. An OLS technique cannot be employed because the OLS assumption that all observations be independent would be violated due to serial correlation of the error terms for observations from the same company. I tested this concern using an OLS fixed-effects model with company dummy variables and with an OLS fixed-effects model with year dummy variables. I found in both cases that serial correlation did exist (an f-stat of 2.68 and 12.52 that intercepts differed for the year and company unrestricted models, respectively).

Results from the GLS levels regressions are presented in Panel A of Table 2. Significance levels reported for coefficients are two-tailed. The results of tests of the hypotheses are reported in Panel B of Table 2. The first coefficient of interest is that on ECE $\left(\beta_{2}\right)$. With a p-value of 0.003 we can reject the null hypothesis that $\beta_{2}$ is equal to 0 in favor of the alternate that $\beta_{2}$ is greater than zero, thus the market positively values environmental capital expenditure for low-polluting firms. The next hypothesis concerns the sum of $\beta_{2}$ and the coefficient of the interaction term ECE*POLLUTE $\left(\beta_{3}\right)$. A p-value of 0.833 leads me to accept the null hypothesis that the sum of the two coefficients is not statistically different from zero. This result is consistent with the hypothesis that the market does not value environmental capital expenditures made by high-polluting firms. In order to test the third hypothesis it is necessary to examine the coefficient on the POLLUTE indicator term, $\left(\beta_{7}\right)$. Testing this coefficient yields a statistically significant but opposite sign result. This result 
is inconsistent with the third hypothesis that the market assesses unrecorded liabilities to high-polluting firms. My result in testing the third hypothesis is the opposite result of that found by CLR. My result is inconsistent with a raising rivals' costs explanation for market valuation of environment capital expenditure. In order for this theoretical explanation to hold the market would need to be anticipating future pollution abatement expenditures for high-polluting firms. Anticipated future expenditures should appear in the form of unrecorded liabilities. The result is still consistent with the other two theoretical explanations for market valuation of environmental capital expenditure.

Table 2: Levels Specification of the Model

Panel A: Results of Level Variables OLS Regression

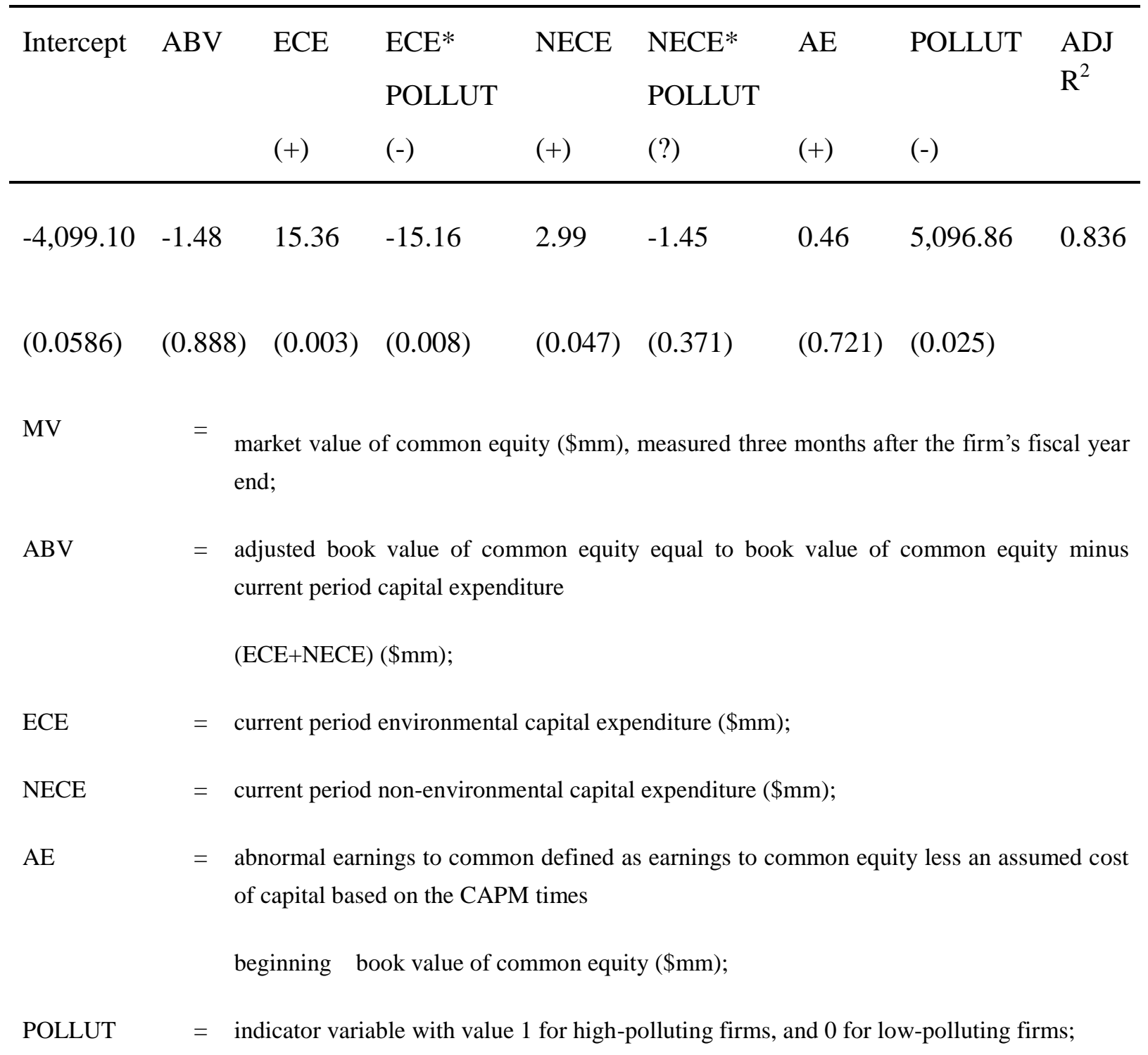




\section{Macrothink

Panel B: Primary Coefficient Tests

Levels Model

\begin{tabular}{lr}
\multicolumn{1}{c}{ Test } & \multicolumn{1}{c}{$\mathrm{p}$-value } \\
$\beta_{2}>0$ & 0.003 \\
$\beta_{2}+\beta_{3}=0$ & 0.833 \\
$\beta_{7}<0$ & 0.025 \\
\hline
\end{tabular}

Results from the changes regressions are in Table 3. In the test of $\mathrm{H} 4 \mathrm{I}$ find that the coefficient on an increase in environmental capital expenditure is negative but not statistically different from zero. I cannot reject the null hypothesis that the market does not value increases in environmental cap ex for low-polluting firms. To test the final hypothesis regarding the market's punishment of increases in environmental cap ex by high-polluting firms I look at the coefficients on the increase in environmental cap ex $\left(\alpha_{2}\right)$ and the interaction term $\left(\alpha_{3}\right)$. With a p-value of 0.032 I reject the null hypothesis that the sum of the two coefficients is zero in favor of the alternate hypothesis that the sum is negative. The result is consistent with the hypothesis that the market punishes high-polluting firms that increase environmental capital expenditure. 


Mllinstitute"

Table 3: Changes Specification of the Model

Panel A: Results of Change Variables OLS Regression

\begin{tabular}{|c|c|c|c|c|c|c|}
\hline \multirow[t]{3}{*}{$\triangle \mathrm{ABV}$} & \multirow{2}{*}{$\Delta \mathrm{ECE}$} & $\Delta \mathrm{ECE}^{*}$ & $\triangle \mathrm{NECE}$ & $\triangle \mathrm{NECE}^{*}$ & $\triangle \mathrm{AE}$ & \multirow{3}{*}{$\begin{array}{l}\text { ADJ } \\
\mathrm{R}^{2}\end{array}$} \\
\hline & & \multicolumn{2}{|l|}{ POLLUT } & \multicolumn{2}{|l|}{ POLLUT } & \\
\hline & $(+)$ & $(-)$ & $(+)$ & $(?)$ & $(+)$ & \\
\hline 0.94 & -8.72 & -3.02 & 12.47 & -12.05 & -.94 & 0.297 \\
\hline$(0.002)$ & $(0.494)$ & $(0.827)$ & $(<0.001)$ & $((<0.001)$ & $(0.043)$ & \\
\hline$\Delta \mathrm{MV}$ & $=$ & $\begin{array}{l}\text { Change in } \\
\text { fiscal year }\end{array}$ & $\begin{array}{l}\text { narket value of } \\
\text { nd; }\end{array}$ & f common equ & ty $(\$ \mathrm{~mm})$, & measured three months after the firm's \\
\hline \multirow[t]{2}{*}{$\Delta \mathrm{ABV}$} & $=$ & \multicolumn{5}{|c|}{$\begin{array}{l}\text { Change in adjusted book value of common equity equal to book value of common equity } \\
\text { minus current period capital expenditure }\end{array}$} \\
\hline & & \multicolumn{5}{|c|}{$(\mathrm{ECE}+\mathrm{NECE})(\$ \mathrm{~mm})$} \\
\hline$\Delta \mathrm{ECE}$ & $=$ & \multicolumn{5}{|c|}{ Change in current period environmental capital expenditure $(\$ \mathrm{~mm})$; } \\
\hline$\Delta \mathrm{NECE}$ & $=$ & \multicolumn{5}{|c|}{$\begin{array}{l}\text { Change in current period non-environmental capital expenditure } \\
(\$ \mathrm{~mm}) \text {; }\end{array}$} \\
\hline$\Delta \mathrm{AE}$ & $=$ & \multicolumn{5}{|c|}{$\begin{array}{l}\text { abnormal earnings to common defined as earnings to common equity less an assumed } \\
\text { change in cost of capital based on the CAPM times }\end{array}$} \\
\hline & & beginning & \multicolumn{4}{|c|}{ book value of common equity ( $\$ \mathrm{~mm})$; } \\
\hline POLLUT & $=$ & indicator va & riable with val & lue 1 for high- & olluting fir & $\mathrm{ms}$, and 0 for low-polluting firms; \\
\hline
\end{tabular}




\section{Macrothink

Panel B: Primary Coefficient Tests

Changes Model

\begin{tabular}{lr} 
Test & \multicolumn{1}{c}{$\mathrm{p}$-value } \\
$\alpha_{2}=0$ & 0.553 \\
$\alpha_{2}+\alpha_{3}<0$ & 0.032 \\
& \\
\hline
\end{tabular}

\section{Conclusions, Limitations and Suggestions for Future Examination}

In examining a sample of pulp and paper industry firms during the period of 1993-2002 I find evidence consistent with environmental economics theories which suggest that markets value environmental capital expenditures. Environmental economics theories offer three possible explanations for market valuation of environmental capital expenditures: "green goodwill," increased incentives to innovate, and the raising of costs for rival firms. I find evidence consistent with the hypothesis that the market values environmental capital expenditures for low-polluting firms but not for high-polluting firms. My findings also suggest that the market does not assess unbooked liabilities to high-polluting firms. These findings are consistent with the "green goodwill" and increased incentives to innovate theories but not with a raising of costs for rival firms theory. In extending the study by Clarkson, Li, and Richardson (2004), I find evidence consistent with the hypothesis that the market does not value increases in environmental capital expenditures by low-polluting firms and that the market punishes high-polluting firms that increase environmental capital expenditures. These findings are important in assessing the effectiveness of environmental regulatory strategy. My findings also provide additional justification for the capitalization of environmental capital expenditures beyond the rational of the long-lived nature of pollution abatement facilities by providing evidence of the incremental economic value of such facilities.

As with any single industry study, my results may not be generalizable beyond this specific industry. An important feature of the pulp and paper industry is the "Best Available Technology" environmental regulatory setting. Another limitation of my study arises from the limited sample size. A limiting assumption of my examination results from proxy for environmental performance. This study assumes that the TRI measure proxies for general environmental performance. Future examination of the issue of market valuation of 
environmental capital expenditure could look at different industries and environmental regulatory settings. Such research could further isolate the economic theories driving the equity market's valuation bifurcation.

\section{References}

Arora, S. and S. Gangopadhyay. (1995) Toward a theoretical model of voluntary overcompliance.Journal of Economic Behavior \& Organization28(3): 289.

Barth, M. E. and M. F. McNichols. (1994). Estimation and market valuation of environmental liabilities relating to Superfund sites.Journal of Accounting Research32: 177.

Campbell, K., S. E. Sefcik, Naomi S. Soderstrom. (2003). Site uncertainty, allocation uncertainty, and superfund liability valuation.Journal of Accounting and Public Policy17(4,5): 331.

Christie, A. A. (1987).On Cross-Sectional Analysis in Accounting Research.Journal of Accounting \& Economics9(3): 231.

Clarkson, P. M., Y. Li, Gordon D. Richardson. (2004). The Market Valuation of Environmental Capital Expenditures by Pulp and Paper Comapnies.The Accounting Review79(2): 329.

Feltham, G. A. and J. A. Ohlson. (1996). Uncertainty resolution and the theory of depreciation measurement.Journal of Accounting Research34(2): 209.

Hughes, K. E. I. (2000).The value relevance of nonfinancial measures of air pollution in the electric utility industry.The Accounting Review75(2): 209.

King, A. A. and M. J. Lenox. (2001) Lean and green?An empirical examination of the relationship between lean production and environmental performance.Production and Operations Management 10(3): 244.

Konar, S. and M. A. Cohen. (1997). Information as regulation: The effect of community right to know laws on toxic emissions. Journal of Environmental Economics and Management32(1): 109.

Lundholm, R. J. (1995). A tutorial on the Ohlson and Feltham/Ohlson models: Answers to some frequently asked questions. Contemporary Accounting Research11(2): 749.

Michael E Porter; Linde, C. V. D. (1995).TOWARD A NEW CONCEPTION OF THE ENVIRONMENT-COMPETITIVENESS RELATIONSHIP.The Journal of Economic Perspectives.9(4): 97.

National Council for Air and Stream Improvement. 2003. A Survey of Pulp and Paper 


\section{Macrothink}

International Journal of Accounting and Financial Reporting

ISSN 2162-3082 2012, Vol. 2, No. 1

Industry Environmental Protection Expenditures-2002. Special Reoport No. 03-07, December. Kalamazoo, MI: National Council for Air and Stream Improvement.

Ohlson, J. A. (2002). Earnings, book values, and dividends in equity valuation: An empirical perspective. Contemporary Accounting Research18(1): 107.

Ohlson, J. A. (1995). Earnings, book values, and dividends in equity valuation.Contemporary Accounting Research11(2): 661.

Salop, S. C. and D. T. Scheffman. (1983). Raising Rivals' Costs.The American Economic Review73(2): 267.

\section{Copyright Disclaimer}

Copyright reserved by the author.

This article is an open-access article distributed under the terms and conditions of the CreativeCommons Attribution license (http://creativecommons.org/licenses/by/3.0/). 